\title{
HAK CIPTA DALAM SUDUT PANDANG NILAI - NILAI PANCASILA
}

\author{
Muhammad Rifqi Fauzi \\ Universitas Indonesia
}

Contact: rifqifauzi12@gmail.com

Diterima: 15 Desember 2020

Direvisi:

Disetujui: 30 Desember 2020

Hak Cipta: (C)2018

Halaman: 16-34

\begin{abstract}
Hak Cipta is a legal protection for authors interest to protect their works, particularly for science, art and literature works. Indonesia has great potency for science, art and literature works. For that reason, it is important for Indonesia to protect those works. In this world, the protection of science, art and literature works is divided into two systems which are Author's Right system and Copyright system. Author's right system recognizes moral right and economic right. On the other hand, Copyright system doesn't recognize moral right. This paper is intended to explain whether Hak Cipta protection in Indonesia to use Author's Right system or Copyright system through the discussion of regulations on Hak.Cipta that ever applied in Indonesia. Those regulations will be seen from the point of view of Pancasila as the nation ideology and Staatsfundamentalnorm. The research method used is normative juridical approach with qualitative method and descriptive data analysis. The conclusion of the research is stated that Indonesia to use Author's Right System. It is because from Auteurswet 1912 until Act No. 28 of 2014 on Hak Cipta regulate moral right and economic right as part of Hak Cipta. From the point of view of Pancasila, Author's Right System is in accordance with five values contained in Pancasila.
\end{abstract}

Keywords: Hak Cipta, Author's Right, Copyright, Pancasila. 


\section{PENDAHULUAN}

Bangsa Indonesia mempunyai pandangan hidup dan karakteristik tersendiri yang bersumber dari nilai-nilai yang dianut Bangsa Indonesia. Nilai-nilai tersebut didapatkan setelah melalui proses yang cukup panjang dalam perjalanan sejarah Bangsa Indonesia, dimulai dari zaman kerajaan Kutai, Sriwijaya, Majapahit, Kerajaan Islam, Kolonialisme Belanda, Pendudukan Jepang hingga masa kemerdekaan saat ini.

Bangsa Indonesia mendasarkan pandangan hidup dalam bermasyarakat dan bernegara pada suatu nilai yang melekat pada bangsa itu sendiri. Nilainilai tersebut yang sudah mendarahdaging terdiri atas nilai ketuhanan, nilai kemanusiaan, nilai persatuan, nilai kerakyatan dan nilai keadilan sosial. Nilai-nilai tersebut dirumuskan dengan nama Pancasila, dimana istilah tersebut diucapkan oleh Ir. Soekarno yang berasal dari salah satu rekannya yang ahli bahasa.

Inspirasi Ir. Soekarno sebagai salah satu founding fathers diilhami oleh petunjuk Tuhan Yang Maha Esa dalam merumuskan nilai - nilai tersebut. Petunjuk dari Tuhan Yang Maha Esa kepada Ir. Soekarno yaitu mengarahkan bahwa dasar negara Indonesia bersumber dari nilai - nilai yang sudah dianut oleh Bangsa Indonesia itu sendiri (Kaelan, 2014: 110). Hal ini selaras dengan pendapat Prof. Notonegoro bahwa untuk mencari asal mula
Pancasila menggunakan teori kausalitas (sebab akibat). Berdasarkan teori kausalitas tersebut, causa materialis Pancasila berasal dari adat kebiasaan, kebudayaan dan agama yang ada di Indonesia. Hal tersebut menegaskan bahwa Bangsa Indonesia merupakan kausa materalis dari Pancasila (Notonegoro, 1975: 32).

Dalam tatanan hukum, Pancasila mempunyai peran yang sangat vital dalam perumusan hukum di Indonesia. Pancasila sebagai norma dasar bagi pembentukan hukum dibawahnya. Hal ini selaras dengan pendapat Hans Kelsen perihal jenjang norma hukum dimana norma hukum itu berjenang dan berlapis lapis, dimana bahwa suatu norma lebih rendah berlaku, bersumber pada norma yang lebih tinggi demikian seterusnya hingga mencapai suatu norma yang tidak dapat ditelusuri lebih lanjut yang bersifat hipotesis dan fiktif yang merupakan grundnorm. Teori tersebut dikembangkan oleh Hans Nawiyasky mengenai hierarki norma yang dikelompokan dalam empat kelompok besar yaitu 1) Staatsfundamentalnorm, 2) Staatsgrundgezeets, 3) Formelee Gezeets, dan 4) Verodnuung. Dalam hal ini Pancasila merupakan Staatsfundamentalnorm (Indriati, 2007: 42-45).

Staatsfundamentalnorm diartikan sebagai suatu norma tertinggi dalam suatu negara yang bersifat pre-supposed dan ditetapkan terlebih dahulu oleh masyarakat dalam suatu negara. Menurut Hans Nawiyasky isi dari 
Staatsfundamentalnorm merupakan norma yang menjadi dasar pembentukan konstitusi dari suatu negara (Indriati, 2007: 46).

$\begin{array}{lrr}\text { Pancasila yang } & \text { menjadi } \\ \text { Staatsfundamentalnorm } & \text { bagi }\end{array}$
pembentukan norma hukum dibawahnya mempunyai peran vital, tak terkecuali bagi pembentukan peraturan menganai Hak Cipta di Indonesia. Pengaturan Hak Cipta di Indonesia sudah dimulai dari masa kolonial Belanda yaitu dengan dikeluarkannya Auteurswet 1912 yang berlaku di negara jajahannya dan berlaku untuk Bangsa Eropa di Hindia Belanda, peraturan tersebut didasari untuk melindungi ciptaan dari Bangsa Eropa di Hindia Belanda (Nainggolan, 2016: 7-9).

Setelah 37 tahun Indonesia merdeka, pengaturan Hak Cipta memasuki babak baru dengan adanya Undang-Undang No. 6 Tahun 1982 Tentang Hak Cipta (selanjutnya disebut UUHC 1982) yang merupakan perjuangan panjang dari aspirasi-aspirasi pencipta atas perlindungan ciptaannya yang mendapat tantangan berupa pembajakan. Setelah terbitnya peraturan tersebut, lahir beberapa undang-undang baru mengenai Hak Cipta yaitu: Undang-Undang No. 7 Tahun 1987 Tentang Perubahan UndangUndang No. 6 tahun 1982 Tentang Hak Cipta (selanjutnya disebut UUHC 1987), kemudian Undang-Undang No. 12 tahun 1997 Tentang Perubahan UU No. 6 tahun 1982 sebagaimana diubah dengan UU No. 7 tahun 1987 tentang Hak Cipta (selanjutnya disebut UUHC 1997), kemudian Undang-Undang No. 19 Tahun
2002 Tentang Hak Cipta (selanjutnya disebut UUHC 2002) yang menyatakan mencabut UU lama tentang Hak Cipta, hingga saat ini Undang-Undang No. 28 Tahun 2014 Tentang Hak Cipta (selanjutnya disebut UUHC 2014) (Saidin, 2016: 15-17).

Perjalanan mengenai peraturan Hak Cipta di Indonesia juga tidak terhindarkan dari berbagai lika - liku. Hal tersebut wajar dikarenakan pengaturan Hak Cipta di Indonesia merupakan transplantasi hukum internasional ke dalam sistem hukum nasional. Dimulai dari pemberlakuan Auteurswet 1912, adopsi Berne Convention serta ratifikasi The Agreement on Trade-Related Aspects of Intellectual Property Rights (TRIPs) sebagai konsekuensi Indonesia yang telah menjadi anggota World Trade Organization (WTO). Tidak hanya itu, pengaturan mengenai Hak Cipta di dunia ini terbagi atas dua sistem dalam perlindungannya yaitu dengan Copyright dan Author's Right yang sedikit banyak mempengaruhi perlindungan Hak Cipta di Indonesia. Acap kali timbul pembahasan dan persoalan apakah peraturan-peraturan Hak Cipta di Indonesia telah sesuai dengan nilai - nilai Pancasila yang merupakan grundnorm dan Staatsfundamentalnorm dalam pembentukan norma hukum di Indonesia.

\section{METODOLOGI PENELITIAN}

Dalam menyusun penulisan ini, penulis menggunakan pendekatan yuridis normatif dimana hukum dikonsepkan 
sebagai apa yang tertulis dalam peraturan perundang-undangan (law in books) atau hukum dikonsepkan sebagai kaidah atau norma yang merupakan patokan berperilaku manusia yang dianggap pantas (Amiruddin \& Asikin, 2012: 118). Penelitian hukum normatif ini diadasrakan kepada bahan hukum primer dan sekunder, yaitu penelitian yang mengacu kepada norma-norma yang terdapat dalam peraturan perundang undangan (Soekanto, 1984: 20).

Pendekatan yang digunakan adalah pendekatan kualitatif yang tidak menggunakan statistik, tetapi melalui pengumpulan data, analisis, kemudian diinterpretasikan. Penelitian ini merupakan penelitian yang menekankan pada pemahaman mengenai masalah masalah dalam kehidupan sosial berdasarkan kondisi realitas atau natural setting yang holistis, kompleks dan rinci (Anggito \& Setiawan, 2018: 9).

Metode pengumpulan data dalam penulisan ini menggunakan studi kepustakaan yang terdiri dari bahan hukum primer berupa Undang - Undang Hak Cipta dari masa ke masa, bahan hukum sekunder berupa buku - buku serta jurnal - jurnal menganai hak cipta dan nilai - nilai Pancasila dan bahan hukum tresier yang berasal dari kamus hukum dan Kamus Besar Bahasa Indonesia.

Penulisan ini dilakukan dengan menggunakan penelitian yang berbentuk deskirptif analitis. Penelitian deskriptif bertujuan untuk memberikan data yang seteliti mungkin tentang manusia, keadaan atau gejala-gejala lainnya (Soekanto, 2004: 10). Selanjutnya analitis merupakan bersifat analisis yang berarti penyelidikan terhadap suatu peristiwa (karangan, perbuatan, dan sebagainya) untuk mengetahui keadaan yang sebenarnya (sebab musabab, duduk perkaranya, dan sebagainya).

\section{HASIL DAN PEMBAHASAN}

\section{Perkembangan Pengaturan dan Pelaksanaan Hak Cipta di Indonesia}

Hak Cipta meripakan suatu hal yang penting bagi perlindungan ciptaan yang telah diusahakan oleh pencipta, selanjutnya dalam Pasal 1 angka 1 UUHC 2014 yang dimaksud Hak Cipta adalah hak eksklusif pencipta yang timbul secara otomatis berdasarkan prinsip deklaratif setelah suatu ciptaan diwujudkan dalam bentuk nyata tanpa mengurangi pembatasan sesuai dengan ketentuan peraturan perundangundangan.

Hak Cipta merupakan salah satu bagian dari Hak Kekayaan Intelektual (selanjutnya disebut HKI) yang secara internasional telah diatur dalam Berne Convention dan TRIPS. HKI sendiri merupakan hak kepemilikan, dimana definisi hak (right) menurut Black Law Dictionary didefinisikan sebagai "as a noun, and taken in an abstract sense, means justice, ethical correctness, or consonance with the rules of law or the principle of morals; a power privilege or immunity guaranted under constitution, statutes or decisional law or claimed as a 
result of long usage; A legally enforceable claim of one person againts another, that the other shall do a given act, or shall not do a given act... Exclusive Right means right to exclude other for certain of time and take into account the limitation" (Black, 1990: 1216).

Kemudian Black Law Dictionary juga mendefinisikan kepemilikan (property) sebagai "that is perculiar or proper to any person that which belongs exclusively to one; In the strict legal sense, an aggregate of rights which are guaranted or protected by government; the word is also commonly used to denote everything which is the subject of ownership, corporeal or incorporeal, tangible or intangible, visible or invisible real or personal, everything that has an exchangeable value or which goes to make up wealth or estate" (Black, 1990: 1187).

Dalam Kitab Undang-Undang Hukum Perdata (KUH Perdata), Pasal 570 KUH Pedata mendefisikan hak kepemilikan sebagai hak untuk menikmati kegunaan sesuatu kebendaan dengan leluasa dan untuk berbuat bebas terhadap kebendaan itu sepenuh penuhnya asal tidak bertentangan dengan undangundang atau peraturan umum yang ditetapkan oleh suatu kekuasaan yang berhak menetapkan dan tidak mengganggu hak-hak orang lain dengan tidak mengurangi kemungkinan akan pencabutan hak itu demi kepentingan umum berdasarkan atas ketentuan undangundang dan dengan pembayaran ganti rugi.
Pemikiran terhadap perlindungan Hak Cipta sudah muncul dengan pemikiran John Locke yang menjelaskan bahwa setiap orang secara alamiah memiliki hak atas dirinya sendiri dan oleh karena itu hasil pekerjaannya yang karena telah melakukan pengorbanan dalam bentuk menemukan, mengolah dan menambahkan kepribadian ke dalam hasil pekerjaannya sebagaimana yang diungkap sebagai berikut:

"...yet every man has a "property" in his own 'person'. This nobody has any right to but himself. The 'labour' of his body and the 'work' of his hands, we may say, are properly his. Whatsoever, then, he removes out of the state that Nature hath provided and left it in, he hath mixed his labour with it, and joined to it something that is his own, and thereby makes it his property" (Locke, 2004: 17-19).

Pemikiran tersebut dilengkapi oleh G.W. Frierich Hegel, dimana kreasi intelektual juga merupakan perwujudan kepribadian (personality) sebagai hak abstrak sebagai manusia eksis dan penghargaan tidak semata - mata hanya hak ekonomi, tetapi juga yang bersifat etis dan moral yang dijadikan sebagai adanya hak moral (Jened, 2014: 7).

Seperti yang telah dijelaskan di atas, bahwa perlindungan Hak Cipta terbagi atas dua sistem yaitu Copyright dan Author's Right. Sistem Copyright sendiri popular di Inggris dan beberapa negara Common Law lainnya. Diawali dengan adanya penemuan mesin cetak oleh William Caxton pada 1476 yang mempermuda proses perbanyakan suatu 
karya tulis, sehingga tidak perlu menulis ulang dengan menggunakan pena. Ditemukannya mesin cetak berkembang hingga munculnya industri percetakan dan dimanfaatkan oleh para publisher untuk menerbitkan karya-karya tulisnya sehingga timbul adanya persaingan antar publisher. Pada 1557, kerajaan memberikan hak monopoli kepada kelompok usaha percetakan di London yang bernama Stationers Company untuk menerbitkan buku.

Namun hak itu hanya bertahan hingga 1694 ketika kerajaan mencabut hak tersebut. Pencabutan tersebut menimbulkan persaingan ekonomi yang tidak baik. Atas dasar tersebut mereka berjuang untuk diadakannya suatu perlindungan hukum dan lahirlah Copyright Act 1710. Dapat dikatakan bahwa sistem Copyright hanya melindungi para perusahaan percetakan untuk mendapatkan hak copy dan hak publish dengan tidak menitikberatkan pada perlindungan si pencipta. Sehingga sistem Copyright tidak mengenal adanya hak moral (Sardjono, 2010: 253-254).

Sistem Copyright yang popular di tradisi hukum Commow Law sangat dipengaruhi oleh pemikiran John Locke perihal kepemilikan yang kaitannya dengan Hak Azasi Manusia, sesuai dengan perkataannya yaitu: "Life, Liberty and Property". Sebagai sistem Copyright, titik tolak perlindungan diberikan kepada obyeknya yaitu ciptaannya (copyrighted work). Oleh karenanya, disyaratkan ciptaan harus ada dalam perwujudannya (fixation), sedangkan unsur keaslian (originality) dan kreatifitas (creativity) dengan derajat yang tidak terlalu tinggi (Jened, 2014: 27-28).

Sementara sistem Author's Right menjelaskan bahwa perlindungan tersebut sebagai sistem reward dan perlindungan personality pencipta. Hak Cipta diberikan kepada pencipta selaku yang memiliki "intellectual personal creation" yang mensyaratkan unsur keaslian dan kreatifitas. Sistem Author's Right diperngaruhi oleh konsep "Right, Ethic and State" dari G.W. Friedrich Hegel yang menjelaskan "The property is, among other things, the means by which an individual could objectively express a personal, singular will. In property 'a person exists' for the first time as reason". Sehingga titik berat perlindungan hak cipta ditujukan pada pencipta dan tidak hanya soal hak ekonomi, melainkan hak moral yang juga penting untuk dilindungi, sesuai dengan norma "Copyright shall protect the author with respect to his intellectual and personal relationship with his work and also with respect to utilization of his work" (Jened, 2014: 26-27).

Adanya perlindungan hak moral juga selaras dengan doctrine of paternity dimana pencipta senantiasa dilekatkan pada ciptaannya dan doctrine of integrity yaitu suatu ciptaan tidak boleh diubah tanpa persetujuan dari penciptanya (Sardjono, 2010: 253-254).

Secara yuridis, Article 6 (1) bis Berne Convention mengatur perihal hak moral sebagai berikut: "Independent of the 
author's economic rights, and even after the the transfer of the said right, the author shall have the right to claim authorship of the work and to object to any distortion, mutilation or other modificationof, or other derogatory action, in relation to the said work, which would be prejudicial to his honor or reputation". Perihal hak moral, Desbois dalam bukunya Le Droit d'auteur menyatakan bahwa Pencipta memiliki hak moral yang mencakup (Damian, 2003: 64):

a. Droit publication, yaitu hak untuk melakukan atau tidak melakukan pengumuman ciptaannya;

b. Droit de repentier, yaitu hak untuk melakukan perubahan yang dianggap perlu atas ciptaannya termasuk menarik dari peredaran ciptaan yang telah diumumkan;

c. Droit au respect, yaitu hak untuk dihargai agar pihak lain tidak mengadakan perubahan atas ciptaannya;

d. Droit a la paternite yaitu hak untuk mencantuman nama pencipta, termasuk untuk tidak menyetujui perubahan nama pencipta yang dicantumkan dan hak untuk mengumumkan sebagai pencipta.

Sebagai negara yang memiliki segudang karya ilmu pengetahuan, seni dan sastra dari rakyatnya, Indonesia juga memiliki pengaturan mengenai Hak Cipta yang memiliki sejarah panjang. Dari Auteurswet 1912 yang merupakan warisan dari kolonial Belanda hingga undang - undang yang terbaru yaitu Undang - Undang No. 28 Tahun 2014 Tentang Hak Cipta.
Perkembangan pengaturan Hak Cipta di Indonesia dimulai dengan diundangkannya Auteurswet 1912 Stb. No. 600 yang efektif berlaku pada 23 September 1912. Tidak lama setelahnya, Belanda mengikatkan diri pada Berne Convention per tanggal 1 April 1913. Kemudian berdasarkan Staatsblad 1931 No. 325, Auteurswet 1912 dinyatakan berlaku di Hindia Belanda (Indonesia) dan efektif per tanggal 1 Agustus 1931. Auteurswet 1912 terus berlaku dari masa Hindia Belanda, Pendudukan Jepang di Indonesia, Indonesia Merdeka hingga setelah Indonesia merdeka hingga tahun 1982. Dasar diberlakukannya Auteurswet 1912 setelah Indonesia merdeka adalah Pasal II Aturan Peralihan UUD 1945 yang berbunyi: "Segala badan negara dan peraturan yang ada masih langsung berlaku, selama belum diadakan yang baru menurut Undang-Undang Dasar ini" (Saidin, 2016: 59-63). Prinsip dasar perlindungan Hak Cipta dalam Auteurswet 1912 adalah kepada pencipta, walaupun kata auter jika diartikan hanya mencakup pengarang saja. Ditambah, dalam Auteurswet 1912 telah mengatur mengenai hak ekonomi dan hak moral pada Pasal 25.

Memanasnya gejolak politik pada periode 1950an hingga 1960an juga mempengaruhi pengaturan Hak Cipta di Indonesia. Akhirnya timbul berbagai masalah yang mempengaruhi perlindungan hak cipta, seperti yang dikemukakan Otto Hasibuan (2008: 8485): 
a. Pada 1958, Indonesia yang pada saat itu adalah masa pemerintahan Kabinet Djuanda menyatakan keluar dari Berne Convention. Ada dua hal yang menjadi alasan keluarnya Indonesia dari Berne Convention. Pertama adalah tensi Indonesia dengan Belanda yang memanas karena perebutan Irian Barat. Pada saat itu keanggotaan Indonesia pada Berne Convention merupakan warisan dari pemerintahan Belanda, yang artinya jika Indonesia bergabung pada Berne Convention maka sama dengan mengakui kedaulatan Belanda. Kedua adalah agar Indonesia leluasa melakukan kegiatan memindahkan ilmu pengetahuan dari luar negeri dengan menejermahkan, meniru, bahkan menyalin;

b. Pemerintah membiarkan Penerbit Balai Pustaka (milik pemerintah) melakukan pelanggaran-pelanggaran Hak Cipta;

c. Pemerintah membiarkan pengarangpengarang Indonesia menyadur karya asing tanpa izin, bahkan tidak menyebutkan nama pengarangnya;

d. Ketidakseriusan pemerintah dan Badan Perwakilan Rakyat untuk membentuk undang-undang Hak Cipta yang baru.

Selama kurun waktu 37 tahun setelah Indonesia meraih kemerdekaannya, pengaturan hak cipta yang saat itu masih diatur dalam Auteurswet 1912 disadari memiliki beberapa kekurangan, utamanya dalam mencakup kepentingan pencipta tanah air. Dimulai dari penyelenggaraan Kongres Kebudayaan Nasional ke - 2 yang diselenggarakan oleh Badan Musyawarah Kebudayaan Nasional (BMKN) di Bandung yang mencetuskan istilah "Hak Cipta" yang merupaka singkatan dari "Hak Pencipta".

Istilah "Hak Cipta" merupakan pilihan dari Prof. Mr. Soetan Mohamad Sjah yang kemudian diterima dalam kongres tersebut. Kemudian pada 17 Februari 1956 beridiri organisasi gerakan perlindungan hak cipta yaitu Organisasi Pengarang Indonesia (OPI) sebagai wadah perkumpulan pengarang pengarang yang bersifat serikat pekerja pengarang dengan tujuan (Simorangkir, 1982: 5-7):

1) Melindungi dan memperjuangkan kepentingan para pengarang;

2) Menaikan nilai karang - mengarang terutama dalam bahasa Indoneisa;

3) Meningkatkan taraf kedudukan kaum pengarang di masyarakat; dan

4) Memupuk kesadaran akan kebudayaan Indonesia.

Hal ini jelas bahwa perjuangan perlindungan Hak Cipta di Indonesia menitik beratkan pada perlindungan pencipta. Dengan semangat sebagai negara dan bangsa yang merdeka, Indonesia mencoba untuk merancang undang-undang Hak Ciptanya sendiri. Pada bulan Oktober 1975 diadakan pertemuan ilmiah oleh Badan Pembinaan Hukum Nasional (BPHN) yang bekerjasama dengan Fakultas Hukum Universitas Udayana yang membahas bahan-bahan ilmiah guna merancang undang-undang Hak Cipta yang bersifat nasional. Dalam pertemuan tersebut turut juga dihadiri unsur DPR, Mahkama Agung, Kejaksaan Agung, beberapa 
departemen, akademisi, Ikatan Penerbit Indonesia (IKAPI), Persatuan Artis Film Indonesia (Parfi), wartawan, pengacara serta berbagai organisasi profesi yang berkaitan dengan perlidungan Hak Cipta. Dalam pertemuan tersebut dibicarakan mengenai ruang lingkup dan pengertian Hak Cipta, RUU Hak Cipta, segi - segi praktis pengelolaan Hak Cipta dan Indonesia dan konvensi internasional tentang Hak Cipta. Berdasarkan hasil pertemuan ilmiah di Bali, kemudian BPHN menyusun RUU Hak Cipta dan disempurnakan dengan diterbitkannya Undang - Undang No. 6 Tahun 1982 Tentang Hak Cipta yang dimuat dalam Lembaran Negara Republik Indonesia Tahun 1982 No. 15 (Nainggolan, 2016: 10-12).

UUHC 1982 mengatur mengenai fungsi dan sifat Hak Cipta yang dicantumkan dalam Pasal 2 UUHC 1982 yaitu Hak cipta adalah hak khusus bagi pencipta maupun penerima hak untuk mengumumkan atau memperbanyak ciptaannya maupun memberi izin untuk itu dengan tidak mengurangi pembatasan-pembatasan menurut peraturan perundang-undangan yang berlaku. Hak untuk mengumumkan meliputi penyiaran, penyuaraan dan pertunjukan agar dapat didengar dan disaksikan oleh orang lain. Hak untuk memperbanyak merupakan hak pengadaan dengan jalan merekam dalam bentuk kaset, piringan hitam, compact disc, buku-buku, film, dll (Ginting, 2019: 384).

Kemudian dalam Pasal 24 ayat (1) UUHC 1982 dijelaskan juga mengenai pencipta atau ahli warisnya berhak untuk menuntut kepada pemegang hak cipta supaya nama pencipta tetap dicantumkan dalam ciptaannya. Kedua pasal tersebut adalah sebagian dari beberapa pengaturan dalam UUHC 1982 yang melindungi kepentingan hak ekonomi pencipta yaitu hak khusus untuk mengumumkan atau memperbanyak ciptaannya serta hak moral yaitu agar nama pencipta tetap melekat pada ciptaannya. Hal ini senada dengan semangat gerakan - gerakan yang peduli terhadap perlindungan Hak Cipta baik hak ekonomi maupun hak moral.

Telah diakomodirnya kepentingan dari pencipta baik dari segi hak ekonomi maupun hak moral, namun dalam rezim UUHC 1982, masih terdapat pelanggaran-pelanggaran yang merugikan, terutama pembajakan. Pembajakan karya lagu dan musik yang telah berwujud rekaman suara dalam bentuk CD, LCD dan VCD menjadi sasaran pembacakan, baik karya cipta dalam negeri maupun asing.

Menurut data Asosiasi Industri Rekaman Indonesia (ASIRI) kerugian yang diakibatkan oleh pembajakan terhadap perusahaan rekaman kaset yang berisikan lagu - lagu dalam negeri mencaiap Rp. 600.000.000,- hingga Rp. 900.000.000,- per bulan. Lebih kurang hingga Rp. 10.000.000.000,- selama kurun 1985-1987 (Atmadja, 2003: 4). Atas maraknya pembajak tersebut dan untuk melindungi Hak Cipta dari pencipta, maka dibentuklah tim kerja 
khusus oleh Presiden Soeharto dengan dasar Keputusan Presiden RI No. 34 Tahun 1986 yang dijuluki "Tim Kepres 34". Atas kerja tim tersebut, lahirlah revisi atas UUHC 1982 yaitu Undang Undang No. 7 Tahun 1987 Tentang Perubahan Undang - Undang No. 6 tahun 1982 Tentang Hak Cipta (Nainggolan, 2016: 17-18).

Dengan didasari adanya perlindungan hak ekonomi dan hak moral dari pencipta, terdapat beberapa poin penting dalam UUHC 1987 yang merevisi UUHC 1982, yaitu (Nainggolan, 2016: 17-18):

1) Peningkatan ancaman hukuman yang semula hanya pidana penjara paling lama tiga tahun dengan denda Rp. 5.000.000,- menjadi pidana penjara paling lama tujuh tahun dan denda paling banyak Rp. 100.000.000,-;

2) Pidana dalam hak cipta menjadi delik biasa; dan

3) Perpanjangan jangka waktu perlindungan Hak Cipta dari selama hidup hingga 25 setelah pencipta meninggal dunia ditambah menjadi perlindungan selama hidup hingga 50 tahun setelah pencipta meninggal dunia.

Sepuluh tahun kemudian, pengaturan Hak Cipta mengalami perubahan yaitu dengan diundangkannya Undang Undang No .12 tahun 1997 Tentang Perubahan UU No. 6 tahun 1982 sebagaimana diubah dengan UU NO 7 tahun 1987 tentang Hak Cipta. Diundangkannya UUHC 1997 sangat kental dengan adanya ratifikasi dari General Agreement on Tariffs and Trade
(GATT) pada 1994 yaitu dengan diundangkannya Undang-Undang No. 7 Tahun 1994 Tentang Pengesahan Agreement Establishing The World Trade Organization (Persetujuan Pembentukan Organisasi Perdagangan Dunia) yang didalamnya terdapat TRIPs yang kemudian menyesuaikan dengan pengaturan yang ada di Berne Convention (Saidin, 2016: 104).

Berkaitan dengan perlindungan Hak Cipta yang diantranya adalah hak moral dan hak ekonomi, UUHC 1997 tidak hanya menitikberatkan kepada pencipta, tetapi juga terhadap hak - hak terkait seperti Pelaku Pertunjukan, Produser Fonogram dan Lembaga Penyiaran. Hal tersebut diatur dalam Pasal 43C yang berbunyi:

(1) Pelaku memiliki hak khusus untuk memberi izin atau melarang orang lain yang tanpa persetujuannya membuat, memperbanyak dan menyiarkan rekaman suara dan atau gambar dari pertunjukannya.

(2) Produser rekaman suara memiliki hak khusus untuk memberi izin atau melarang orang lain yang tanpa persetujuannya memperbanyak karya rekaman suara atau bunyi.

(3) Lembaga penyiaran memiliki hak khusus untuk memberi izin atau melarang orang lain yang tanpa persetujuannya membuat, memperbanyak dan menyiarkan ulang karya siarannya melalui transmisi dengan atau tanpa kabel, atau melalui sistem elektromagnetik lainnya.

Kehadiran UUHC 1997 yang telah 
mengakomodir berbagai ketentuan internasional tidak serta merta menghadirkan perlindungan bagi pencipta. Terbukti bahwa pada 1998, Indonesia masuk dalam Priority Watch List untuk kasus - kasus pelanggaran HKI yang dikeluarkan oleh United State Trade Representative karena sudah tergolong berat dan perlu diprioritaskan untuk diawasi. Kemudian selain terkait pelanggaran HKI di Indonesia yang tidak kunjung membaik, pada 1998 telah terjadi reformasi dan untuk menyesuaikan diri dengan konsep reformasi hukum nasional UUHC 1997 dicabut dan diganti dengan Undang Undang No. 19 Tahun 2002 Tentang Hak Cipta yang berlaku pada 29 Juli 2003 (Nainggolan, 2016: 23-24).

Untuk pertama kalinya, dalam UUHC 2002 diatur secara rinci mengenai hak moral dan hak ekonomi yang merupakan bagian dari Hak Cipta pencipta. Pasal 24 UUHC 2002 berbunyi:

(1) Pencipta atau ahli warisnya berhak menuntut Pemegang Hak Cipta supaya nama Pencipta tetap dicantumkan dalam Ciptaannya.

(2) Suatu Ciptaan tidak boleh diubah walaupun Hak Ciptanya telah diserahkan kepada pihak lain, kecuali dengan persetujuan Pencipta atau dengan persetujuan ahli warisnya dalam hal Pencipta telah meninggal dunia.

(3) Ketentuan sebagaimana dimaksud pada ayat (2) berlaku juga terhadap perubahan judul dan anak judul Ciptaan, pencantuman dan perubahan nama atau nama samaran Pencipta.

(4) Pencipta tetap berhak mengadakan perubahan pada Ciptaannya sesuai dengan kepatutan dalam masyarakat.

Sementara untuk hak ekonomi diatur pada Pasal 2 ayat (1) UUHC 2002 yang berbunyi: hak Cipta merupakan hak eksklusif bagi Pencipta atau Pemegang Hak Cipta untuk mengumumkan atau memperbanyak Ciptaannya, yang timbul secara otomatis setelah suatu ciptaan dilahirkan tanpa mengurangi pembatasan menurut peraturan perundang-undangan yang berlaku.

Perkembangan ekonomi kreatif yang menjadi salah satu andalan perekonomian Indonesia dan pesatnya perkembangan teknologi, informasi dan komunikasi yang mengharuskan adanya perubahan undang - undang Hak Cipta, dimana adanya Hak Cipta menjadi perlindungan terhadap industry kreatif (Nainggolan, 2016: 29). Menurut World Intellectual Property Organization (WIPO) pada tahun 2008, kontribusi industri kreatif di Amerika Serikat mencapai 11,12\% dari Produk Domestik Bruto (PDB) dengan tenaga kerja sebesar 8,49\%. Di Korea Selatan, industry kreatif berkontribusi sebesar 8,67\%. Untuk Indonesia, menurut Kementerian Perdagangan pada 2002-2005, industri kreatif mampu menyerap rata-rata 5,4 juta pekerja dengan produktivitas $\mathrm{Rp}$. 19.500.000,- per pekerja per tahun (Adriasyah, 2010: 86-87). Penting rasanya untuk terus meningkatkan industri kreatif dengan perlindungan hak 
moral dan hak ekonomi pencipta melalui undang-undang hak cipta yang baru.

Dilatarbelakangi hal-hal di atas, maka Undang-Undang No. 28 Tahun 2014 Tentang Hak Cipta diundangkan 16 Oktober 2014 dan ditempatkan dalam Lembaran Negara Republik Indonesia Tahun 2014 Nomor 266. Beberapa hal penting hadir dalam perlindungan hak moral dan hak ekonomi dari pencipta, seperti pada Pasal 4 UUHC 2014 yaitu Hak Cipta sebagaimana dimaksud dalam Pasal 3 huruf a merupakan hak eksklusif yang terdiri atas hak moral dan hak ekonomi. Hak moral yang dijelaskan pada Pasal 5 ayat (1) UUHC 2014 berbunyi:

a. Hak moral sebagaimana dimaksud dalam Pasal 4 merupakan hak yang melekat secara abadi pada diri Pencipta untuk:

b. tetap mencantumkan atau tidak mencantumkan namanya pada salinan sehubungan dengan pemakaian Ciptaannya untuk umum;

c. menggunakan nama aliasnya atau samarannya;

d. mengubah Ciptaannya sesuai dengan kepatutan dalam masyarakat;

e. mengubah judul dan anak judul Ciptaan; dan

f. mempertahankan haknya dalam hal terjadi distorsi Ciptaan, mutilasi Ciptaan, modifikasi Ciptaan, atau hal yang bersifat merugikan kehormatan diri atau reputasinya.

Untuk hak ekonomi juga diatur secara rinci dalam Pasal 9 ayat (1) UUHC 2014 yaitu:

a. penerbitan Ciptaan; b. Penggandaan Ciptaan dalam segala bentuknya;

c. penerjemahan Ciptaan;

d. pengadaptasian, pengaransemenan, atau pentransformasian Ciptaan;

e. Pendistribusian Ciptaan atau salinannya;

f. pertunjukan Ciptaan;

g. Pengumuman Ciptaan;

h. Komunikasi Ciptaan; dan

i. penyewaan Ciptaan.

Kemudian hadirnya pengaturan mengenai Lembaga Manajemen Kolektif (LMK) sebagaimana yang dimaksud pada Pasal 1 angka 22 yaitu institusi yang berbentuk badan hukum nirlaba yang diberi kuasa oleh Pencipta, Pemegang Hak Cipta, dan/atau pemilik Hak Terkait guna mengelola hak ekonominya dalam bentuk menghimpun dan mendistribusikan royalti. Pengaturan mengenai LMK menjadi semangat bagi pencipta untuk membantu mereka dalam pendistribusian royalti dalam melaksanakan hak ekonominya.

Latar belakang hadirnya LMK adalah dalam dunia musik, pencipta lagu untuk mendapatkan hasil dari ciptaannya biasanya akan menghubungi produser rekaman untuk lagu ciptaannya direkam yang selanjutnya diperbanyak kemudian dijual kepada masyarakat. Disini, produser rekaman mendapatkan lisensi dari pencipta lagu berupa hak merekam lagu, hak memperbanyak rekaman lagu dan hak menjual lagu. Namun, pencipta masih mempunyai beberapa hak di dalam lagunya yaitu hak menampilkan, hak menyiarkan, hak mengadaptasikan, dll. 
Tidak dapat dipungkiri, kemungkinan suatu lagu dapat menjadi hits atau mendapat sambutan yang baik di masyarakat. Lagu tersebut dieksploitasi secara komersial dengan berbagai macam cara seperti disiarkan di radio, televisi, disebarkan melalui internet serta dipakai sebagai nada dering atau nada tunggu. Hingga dieksploitasi untuk keperluan tempat hiburan, mall, pesawat, kereta api, dll.

Tentu dengan banyaknya eksploitasi secara komersial atas ciptaan lagu tersebut membuat pencipta kerepotan dalam menarik royalti untuk memastikan hak ekonominya tidak dikurangi sedikitpun. Dalam hal ini peran LMK sangat krusial untuk mendistribusikan hak ekonomi pencipta lagu, dengan dasar kuasa dari si pencipta kemudian LMK akan menarik royalti hasil dari eksploitasi lagu tersebut secara komersil dan memberikannya kepada pencipta (Nainggolan, 2011: 173).

Penjelasan mengenai perkembangan pengaturan Hak Cipta di Indonesia memperlihatkan bahwa perlindungan Hak Cipta di Indonesia menggunakan sistem Author's Right yang mengenal adanya hak moral dan hak ekonomi dalam Hak Cipta. Semangat mengenai perjuangan perlindungan Hak Cipta pun ditunjukan kepada pencipta, bukan kepada publisher.

Sistem Author's Right dapat dicontohkan ketika buku Laskar Pelangi karya penulis Andrea Hirata ingin diubah dalam bentuk film. Dalam hal ini permintaan izin atas perubahan ekspresi tersebut tidak ditujukan kepada penerbit buku Laskar Pelangi, melainkan kepada Andrea Hirata selaku penulis naskah dari buku Laskar Pelangi. Kemudian ketika buku yang berjudul Filosofi Kopi karya Dewi Lestari, yang cukup tenar di kalangan pemuda ingin diterjemahkan ke dalam bahasa Inggris. Pihak yang ingin menerjemahkan harus meminta izin tersebut kepada Dewi Lestari selaku penulis naskah buku Filosofi Kopi, bukan kepada publisher. Berlaku juga untuk perubahan ekspresi dari buku ke seni teater. Seperti seni teater yang berjudul Perempuan Perempuan Chairil yang merupakan adaptasi dari buku yang berjudul Chairil karya Hasan Aspahani. Pihak yang ingin mengubah ekspresi menjadi seni teater harus mendapat izin terlebih dahulu Hasan Aspahani perihal pengubahan ekspresi, terlebih lagi Hasan Aspahani juga berhak atas hak ekonomi hasil dari seni teater Perempuan-Perempuan Chairil.

Begitu juga dalam hal lagu dan musik, jika terdapat seseorang yang ingin menyanyikan lagu Cantik yang dipopulerkan oleh Kahitna dan diciptakan oleh Yovie Widianto, permintaan izin atas perubahan genre tersesebut ditujukan kepada Yovie Widianto selaku pencipta, bukan kepada perusahaan rekaman yang memiliki hak memperbanyak atas rekaman lagu tersebut yang didasari izin lisensi dari pencipta lagu. Selain perubahan genre kegiatan komersial atas lagu acap kali dalam berbentuk soundtrack iklan produk tertentu. Dan tidak jarang, 
terdapat beberapa lirik dari lagu tersebut yang diubah untuk kepentingan marketing. Oleh karenanya, izin dari si pencipta lagu sangat penting sebagai implementasi hak moral atas lagu tersebut dan si pencipta juga berhak atas hak ekonomi berupa royalti dari hasil kegiatan pengiklanan tersebut.

\section{Hak Cipta Dimaknai dalam Sudut Pandang Nilai - Nilai Pancasila}

Pancasila sebagai dasar negara dan Staatsfundamentalnorm memiliki peran yang penting dalam hukum di Indonesia. Sebagai dasar negara, Pancasila memiliki kedudukan sebagai berikut (Kaelan, 2014):

a. Pancasila sebagai dasar negara adalah sumber dari segala sumber tertib hukum Indonesia. Dengan demikian, Pancasila merupakan asas kerohanian hukum Indonesia yang dalam Pembukaan Undang-Undang Negara Republik Indonesia dijelmakan lebih lanjut ke dalam empat pokok pikiran.

b. Meliputi suasana kebatinan (Geislichenhintergrund) dari UUD 1945.

c. Mewujudkan cita-cita hukum bagi dasar negara (baik hukum dasar tertulis maupun tidak tertulis).

d. Mengandung norma yang mengharuskan UUD mengandung isi yang mewajibkan pemerintah dan lain-lain penyelenggara negara (termasuk penyelenggara partai dan golongan fungsional) memegang teguh cita-cita moral rakyat yang luhur. e. Merupakan sumber semangat abadi UUD 1945 bagi penyelenggaraan negara, para pelaksana pemerintahan. Hal tersebut dapat dipahami karena semangat tersebut adalah penting bagi pelaksanaan dan penyelenggaraan negara karena masyarakat senantiasa tumbuh dan berkembang seiring dengan perkembangan zaman dan dinamika masyarakat.

Kedudukan Pancasila sebagai dasar negara sangat berhubungan bahwa Pancasila sebagai suatu norma dasar dalam penyelenggaraan bernegara yang menjadi sumber dari segala sumber hukum sekaligus cita - cita hukum (rectidee) baik tertulis maupun tidak tertulis. Cita hukum ini mengarahkan pada kesamaan kepentingan dari masyarakat (Direktorat Jenderal Pembelajaran dan Kemahasiswaan Kementerian Riset Teknologi dan Pendidikan Tinggi Republik Indonesia, 2016: 81).

Secara terminologis atau secara istilah, dasar negara dapat diartikan sebagai landasan dan sumber dalam membentuk dan menyelenggarakan negara. Dasar negara juga dapat diartikan sebagai sumber dari segala sumber hukum negara. Secara teoretik, istilah dasar negara, mengacu kepada pendapat Hans Kelsen, disebut a basic norm atau Grundnorm (Kelsen, 1970: 8).

Kemudian Pancasila sebagai Staatsfundamentalnorm berarti sebagai suatu norma tertinggi dalam suatu negara yang bersifat pre-supposed dan 
ditetapkan terlebih dahulu oleh masyarakat dalam suatu negara. Menurut Hans Nawiyasky isi dari Staatsfundamentalnorm merupakan norma yang menjadi dasar pembentukan konstitusi dari suatu negara (Indriati, 2007: 46).

Telah dijelaskan bahwa pengaturan perlindungan Hak Cipta di Indonesia menggunakan sistem Author's Right yang mengakui adanya hak moral dan hak ekonomi pencipta. Semangat sistem Author's Right di Indonesia juga berada pada setiap undang - undang tentang Hak Cipta. Dalam setiap nafas undang-undang di Indonesia, tidak terkecuali tentang perlindungan Hak Cipta harus mengedepankan nilai-nilai Pancasila di dalamnya. Nilai-nilai tersebut diantaranya adalah nilai ketuhanan, nilai kemanusiaan, nilai persatuan, nilai kerakyatan dan nilai keadilan.

Pertama merupakan nilai ketuhanan dari sila pertama yaitu "Ketuhanan Yang Maha Esa" yang pada hakikatnya terletak pada keyakinan bangsa Indonesia Tuhan sebagai penjamin prinsip - prinsip moral. Artinya perilaku warga negara harus berlandaskan atas nilai - nilai moral yang berasal dari norma agama. (Direktorat Jenderal Pembelajaran dan Kemahasiswaan Kementerian Riset Teknologi dan Pendidikan Tinggi Republik Indonesia, 2016) Hal ini senada pada pengaturan Hak Cipta di Indonesia yang menggunakan sistem Author's Right yang menghargai adanya hak moral dan hak ekonomi pencipta sebagai penghargaan hasil kerja keras dan jeri payah dari pencipta. Landasan norma agama yang menjadi semangat sila pertama ini juga sangat menghargai kerja keras dan ilmu pengetahuan.

Dalam Al Qur'an, Surat At-Taubah ayat 105 dijelaskan bahwa "Dan Katakanlah: Bekerjalah kamu, maka Allah dan RasulNya serta orang-orang mukmin akan melihat pekerjaanmu itu, dan kamu akan dikembalikan kepada (Allah) Yang Mengetahui akan yang gaib dan yang nyata, lalu diberitakan-Nya kepada kamu apa yang telah kamu kerjakan". Imam Bukhori meriwayatkan dalam hadis No 1.470, Nabi Muhammad Bersabda: "Sesungguhnya seseorang dari kalian pergi mencari kayu bakar yang dipikul di atas pundaknya itu lebih baik daripada meminta-minta kepada orang lain, baik diberi atau tidak".

Alkitab menjelaskan, tepatnya pada Amsal 20:15 bahwa "Sekalipun ada emas dan permata banyak, tetapi yang paling berharga ialah bibir yang berpengetahuan". Kemudian dalam Kitab Veda, dalam Sloka Rgveda X. 117.7 menyatakan bahwa "Sebuah mata bajak yang membajak menghasikan padipadian, seorang laki-laki yang berjalan menteberangi jalanan. Seorang laki-laki yang terpelajar menyanyikan mantramantra Veda, adalah lebih unggul daripada seorang yang tetap diam. Orang yang dermawan melebihi orang yang tidak menolong temannya". Dapat dipahami bahwa ajaran - ajaran agama yang menjadi hakikat sila pertama sangat menghargai kerja keras. Senada dengan semangat sistem Author's Right yang 
menghargai kerja keras pencipta. Hal ini berbeda dengan sistem Copyright yang lebih menekankan hak terhadap publisher.

Kedua adalah nilai kemanusian dari sila kedua yaitu "Kemanusiaan Yang Adil Dan Beradab" yang pada hakikatnya sebagai negara yang berkemanusiaan sudah tentu berkewajiban melindungi seluruh warganya serta seluruh tumpah darahnya. Oleh karenanya negara wajib melindungi hak - hak asasi manusia warganya serta mewujudkannya. Hal ini telah disampaikan dalam Pasal 27, 28, 29, 30 dan 31 UUD NRI 1945. Dimana negara berkewajiban mengembangkan harkat dan martabat manusia, bahkan negara menempatkan moral kemanusiaan sebagai moral negara dan penyelenggara pemerintahan negara (Kaelan, 2014: 165).

Pasal 27 ayat (2) UUD NRI 1945 menjelaskan tiap-tiap warga negara berhak atas pekerjaan dan penghidupan yang layak bagi kemanusiaan. Hal ini senada dengan sistem Author's Right dalam perlindungan Hak Cipta bagi pencipta, karena perlindungan hak moral dan hak ekonomi sepenuhnya ditujukan kepada pencipta. Pencipta berhak atas imbalan dari hasil jerih payahnya menghasilkan suatu ciptaan untuk penghidupan yang layak bagi dirinya. Atas dasar tersebut lah pengaturan pengaturan menganai Hak Cipta di Indonesia melindugi hak moral dan hak ekonomi dari pencipta.

Ketiga adalah nilai persatuan dari sila
"Persatuan Indonesia" yang memiliki pandangan filosofis bahwa kodrat manusia adalah makhluk individu yang memiliki ciri dan kepribadian khas namun juga sekaligus sebagai makhluk sosial. Sebagai makhluk Tuhan Yang Maha Esa manusia tidak diciptakan secara individu, tetapi sebagai warga masyarakat. Oleh karenanya kesadaran moralitas multikultural hadir agar perbedaan tidak diperuncing, melainkan komitmen untuk menyatukan pandangan dan tujuan dalam kehidupan yang lebih mulia (Kaelan, 2014: 167).

Keempat adalah nilai kerakyatan dari sila "Kerakyatan Yang Dipimpin Oleh Hikmat Kebijaksanaan Dalam Permusyawaratan/Perwakilan". Nilai tersebut erat dengan musyawarah mufakat. Prioritas utama dalam musyawarah mufakat tidak hanya perihal suara terbanyak, tetapi mengenai kualitas atau bobot dari suatu usulan atau pembahasan itu sendiri. Hal tersebut yang seharusnya dimaknai dalam semangat nilai kerakyatan dalam musyawarah dan mufakat, dikarenakan muswarah dan mufakat ini bukan hanya untuk kepentingan mayoritas tetapi untuk kepentingan bersama (Syamsudin et al., 2009: 78).

Kedua sila tersebut tidak dibahas secara terpisah, dikarenakan kedua sila tersebut melandasi semangat para pencipta dalam mewujudkan perlindungan Hak Cipta baik hak moral dan hak ekonomi secara ideal. Diantaranya Kongres Kebudayaan Nasional oleh BMKN, Pertemuan Ilmiah Oktober 1975 di Bali dan berdirinya OPI serta organisasi - organisasi pencipta 
lainnya yang berkaitan dengan Hak Cipta diselimuti oleh sila ketiga dan keempat. Semangat untuk melindungi pencipta baik hak moral maupun hak ekonomi semakin menegaskan bahwa sistem Author's Right hadir di Indonesia. Semangat utama beberapa pertemuan dan organisasi tersebut adalah melindungi pencipta, bukan hanya sekedar publisher saja seperti sistem Copyright. Ini dikarenakan penciptalah yang bekerja keras untuk mewujudkan suatu ciptaannya sehingga pantas mendapatkan imbalan yang layak.

Kelima adalah nilai keadilan dari sila "Keadilan Sosial Bagi Seluruh Rakyat Indonesia". Makna yang terkandung adalah suatu tatanan masyarakat yang adil dan makmur sejahtra lahiriah dan baitniah dimana setiap warga negara mendapatkan sesuatu yang menjadi haknya sesuai dengan esensi adil dan beradab. Nilai keadilan bukan hanya sebatas menjadi salah satu bagian dari dasar negara saja, namun merupakan tujuan yang harus dilaksanakan. Nilai keadilan mempunyai arti yang sangat luas, yang berinti pada pokok pikiran setiap warga negara dapat menikmati hidup terhormat, tercukupi kebutuhan hidupnya, dan memperoleh kesempatan untuk mengkesploitasi bakat untuk kepentingan pribadi maupun masyarakat (Syamsudin et al., 2009: 80).

Nilai keadilan selaras dengan sistem Author's Right yang dilaksanakan di Indonesia, dikarenakan pencipta mendapatkan apa yang menjadi hak atas jerih payahnya yaitu hak moral dan hak ekonomi. Tidak adil rasanya jika hak tersebut berada di tangan publisher. Hak pencipta agar namanya tidak dipisahkan dari ciptaannya serta berhak atas memperbanyak dan mengumumkan hasil ciptaannya menjadi implementasi dari nilai keadilan. Nilai keadilan juga yang melandasi kritik atas sistem Copyright yang menitikberatkan perlindungan kepada publisher, bukan kepada pencipta.

\section{KESIMPULAN}

Berdasarkan hasil penelitian dan pembahasan di atas, maka dapat disimpulkan bahwa:

1. Indonesia sebagai negara dengan potensi daya kreasi warganya yang melimpah sudah tentu wajib mempunyai perlindungan Hak Cipta yang baik. Perlindungan ini demi kesejahteraan dari pencipta itu tersebut. Pengaturan perlindungan Hak Cipta di Indonesia, sejak Auteurswet 1912 hingga Undang Undang No. 28 Tahun 2014 Tentang Hak Cipta menunjukan bahwa perlindungan Hak Cipta di Indonesia menggunakan sistem Author's Right dan bukan Copyright. Hal ini juga dilandasi semangat para pencipta di Indonesia untuk tetap melindungi karya-karyanya dari sisi hak moral dan hak ekonomi. Sistem Author's Right di Indonesia ditandai dengan perlindungan Hak Cipta yang berfokus pada pencipta, bukan kepada publisher. Perlindungan Hak Cipta tersebut terdiri atas hak ekonomi dimana pencipta berhak atas hak mengumumkan dan hak 
memperbanyak ciptaannya. Serta perlindungan hak moral sebagai bagian dari doctrine of paternity dimana pencipta senantiasa dilekatkan pada ciptaannya dan doctrine of integrity yaitu suatu ciptaan tidak boleh diubah tanpa persetujuan dari penciptanya.

2. Dilihat dalam sudut pandang nilainilai Pancasila, dijelaskan juga bahwa kelima nilai yang terkandung dalam kelima sila yaitu: pertama, nilai ketuhanan yang melandasi bangsa Indonesia untuk bertindak sesuai dengan norma agama menyatakan bahwa konsep penghargaan atas kerja keras seseorang termasuk kerja keras pencipta dalam menghasilkan karya ciptaannya menjadi suatu hal yang sangat dihargai. Kedua, nilai kemanusiaan yang melandasi bahwa negara yang berkemanusiaan sudah tentu berkewajiban melindungi seluruh warganya serta seluruh tumpah darahnya, dalam hal ini negara memberi perlindungan atas pencipta atas kerja keras untuk mewujudkan karya ciptaannya dengan perlindunga Hak Cipta yang terdiri atas hak moral dan hak ekonomi. Ketiga, nilai persatuan yang melandasi agar perbedaan tidak dipertajam, melainkan membubuhkan semangat untuk menyatukan pandangan dan tujuan dalam kehidupan yang lebih mulia dan yang keempat, nilai kerakyatan yang erat dengan musyawarah mufakat dengan rioritas utama dalam musyawarah mufakat tidak hanya perihal suara terbanyak, tetapi mengenai kualitas atau bobot dari suatu usulan atau pembahasan itu sendiri. Kedua sila tersebut mengiringi semangat dari Kongres Kebudayaan Nasional oleh BMKN, Pertemuan Ilmiah Oktober 1975 di Bali dan berdirinya OPI serta organisasi - organisasi pencipta lainnya yang berkaitan dengan Hak Cipta untuk memperjuangkan Hak Cipta dari pencipta, baik hak moral maupun hak ekonomi. Kelima, nilai keadilan yang melandasi pada pokok pikiran setiap warga negara dapat menikmati hidup terhormat, tercukupi kebutuhan hidupnya, dan memperoleh kesempatan untuk mengkesploitasi bakat untuk kepentingan pribadi maupun masyarakat semakin menunjukan bahwa perlindungan dalam sistem Author's Right yaitu perlindungan Hak Cipta baik hak moral dan hak ekonomi yang ditujukan kepada pencipta atas imbalan kerja kerasnya dalam mewujudkan suatu ciptaan.

\section{DAFTAR PUSTAKA}

Adriasyah, Y. (2010). Mencari Tempat Terhormat Indonesia, Mozaik Pemikiran. PT Alumni.

Amiruddin, \& Asikin, Z. (2012). Pengantar Metode Penelitian Hukum. RajaGrafindo.

Anggito, A., \& Setiawan, J. (2018). Metodologi Penelitian Kualitatif. CV Jejak. 
Atmadja, H. T. (2003). Hak Cipta - Musik

Atau Lagu. UI-Press.

Black, H. C. (1990). Black's Law Dictionary, Sixth ed. St. Paul Minn.

Damian, E. (2003). Hukum Hak Cipta. PT Alumni.

Direktorat Jenderal Pembelajaran dan Kemahasiswaan Kementerian Riset Teknologi dan Pendidikan Tinggi Republik Indonesia. (2016). Pendidikan Pancasila Untuk Perguruan Tinggi. Direktorat Jenderal Pembelajaran dan Kemahasiswaan Kementerian Riset Teknologi dan Pendidikan Tinggi Republik Indonesia.

Ginting, A. R. (2019). Peran Lembaga Manajemen Kolektif Nasional Dalam Perkembangan Aplikasi Musik Streaming. Jurnal Ilmiah Kebijakan Hukum, 13, 379-398.

Hasibuan, O. (2008). Hak Cipta di Indonesia Tinjauan Khusus Hak Cipta Lagu. PT Alumni.

Indriati, M. F. (2007). Ilmu Perundang Undangan (1): Jenis, Fungsi, Materi Muatan. Kanisius.

Jened, R. (2014). Hukum Hak Cipta (Copyright Law). Citra Aditya Bakti.

Kaelan, H. (2014). Pendidikan Pancasila. Paradigma.

Kelsen, H. (1970). The Pure Theory of Law, Translation from the Second (Revised and Enlarged). University of California Press.
Locke, J. (2004). The Second Treatise of Government. Banes \& Noble Publishing,Inc.

Nainggolan, B. (2011). Pemberdayaan Hukum Hak Cipta dan Lembaga Manajemen Kolektif. PT Alumni.

Nainggolan, B. (2016). Komentar UndangUndang Hak Cipta. PT Alumni.

Notonegoro. (1975). Pancasila Secara Ilmiah Populer. Pantjuran Tudjuh.

Saidin, O. (2016). Sejarah dan Politik Hukum Hak Cipta. RajaGrafindo.

Sardjono, A. (2010). Hak Cipta Bukan Hanya Copyright. Jurnal Hukum Dan Pembangunan, 40, 252-269.

Simorangkir, J. C. T. (1982). Undang Undang Hak Cipta 1982 Cetakan I. Penerbit Djembatan.

Soekanto, S. (1984). Pengantar Penelitian Hukum. UI Press.

Soekanto, S. (2004). Penelitian Hukum Normatif. Raja Grafindo Persada.

Syamsudin, M., Munthola, Parmono, K., Akhwan, M., \& Rohiatudin, B. (2009). Pendidikan Pancasila, Menempatkan Pancasila Dalam Konteks Keislaman dan Keindonesiaan. Total Media. 